\title{
胃潰瘍の成因と外科治療
}

東京慈恵会医科大学第 2 外科

\begin{tabular}{|c|c|c|c|c|}
\hline 中村 & 紀夫 & 桜井 & 健彦 & 長州 \\
\hline 坂口友 & 反次朗 & 田村 & 茂樹 & 小山 \\
\hline 原 & 伸一 & 小野 & 良実 & 向島 \\
\hline 池内 & 準次 & 長尾 & 房大 & \\
\hline
\end{tabular}

\section{SURGICAL TREATMENT OF GASTRIC ULCER AS CONSIDERED ITS ETIOLOGIC ASPECT}

\author{
Norio NAKAMURA, Takehiko SAKURAI, Takao NAGASU, Yujiro SAKAGUCHI, \\ Shigeki TAMURA, Atsushi KOYAMA, Shinichi HARA, Yoshimi ONO, \\ Yu MUKOJIMA, Junji IKEUCHI and Fusahiro NAGAO \\ 2nd Department of Surgery, Jikei University School of Medicine
}

索引用語：腺境界, 萎縮性胃炎, 胃底腺潰煌, 血管構筑, 実験潰瘍

はじめに

大井によれば，胃潰晹の発生部位は胃粘膜構造や胃筋 構造からみて, 解剖学的特性を有しており, 胃粘膜構造 からは，胃白腺，幽門腺境界部（腺境界）に接した幽門 腺領域に, 胃筋構造からは, 内側斜走筋束と境界輸状筋 束とに囲まれた部位に発生するといわれてきた。

しかし，その後の検討により，胃潰瘍の約 $10 \%$ ，高 位の胃底腺領域汇認められ, 潰場の発生因子として, 解 剖学的な特性に加光てその他にも, 重要な Back ground があると考兄られた。 そして潰啺胃における腺境界の位 置と潰瘍の発生部位, 胃粘膜変化の状態, 胃壁の血管変 化との関連について，胃に粗大病変のない，いわゆる no ulcer 例，十二指腸潰瘍例を対照として検討を加劣， あわせて実験的慢性潰煌の発生を試みた。

\section{溃癞の発生部位と腺境界}

当教室における最近 6 年間の, 胃潰瘍264例について, 組織学的に 発生部位を検討すると胃角部隤場は236個 (89.4\%) であり，胃底腺潰場28個（10.6\%)であっ た.（図 1) この胃底腺潰晹は, 通常の切除線では切除

* 第13回日消外総会シンポ 1

胃潰瘍（急性ならびに慢性）の成因と外科治療
図 1 僈性潰㾨の発生部位 昭和 46 年〜昭和 52 年

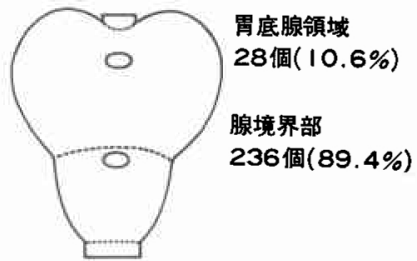

胃潰場 264個の組織学的発生部位をみると腺境 界に発生したもの 236個 (89.4\%), 胃底腺領域に

発生したもの28個（10.6\%）であった。

しえない, いわゆる高位潰瘍43例のうち，組織学的に胃 底腺内に発生したるので, 残りの15例のうち，12例は粘 膜の萎縮性变化が強く, 腺境界が決定できなかったるの であり，3 例は腺境界幽門側発生しているるのであっ た。

このように, 腺境界部は, 胃潰瘍の発生部位としてき わめて重要な意味をむっているとい克るが，高位潰瘍例 にみられるように, 必ずしも解剖学的部位のみで, 潰瘍 の発生ならびに慢性化は説明しえない。

用粘膜変化について

潰瑝と胃粘膜変化との関連を検討したが，胃粘膜変化 
因 2 胃底腺領域における萎縮境界

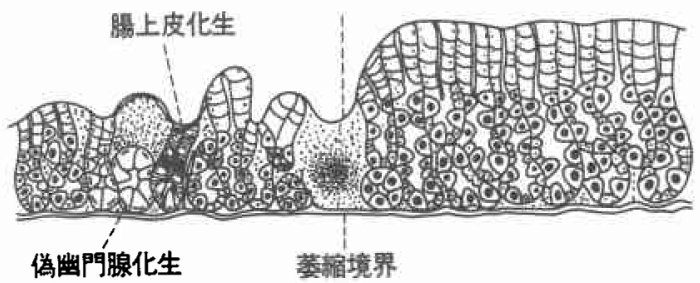

(1979.4)

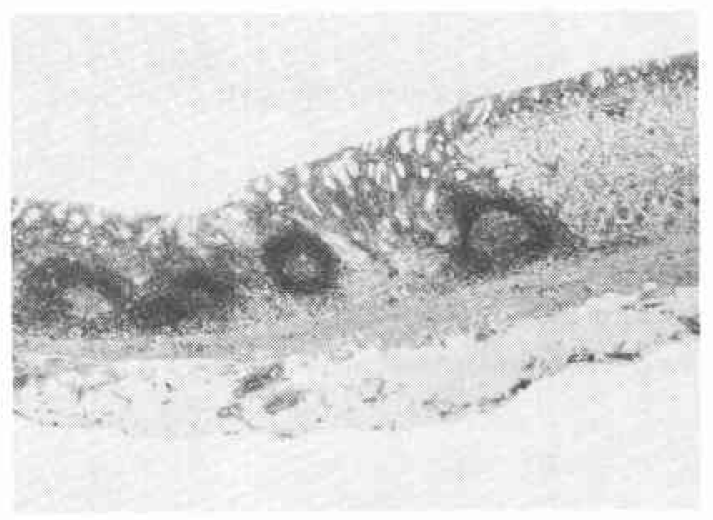

胃底腺領域における萎縮境界のシェーマと組織 像で, リンパロ胞の增生や腸上皮化生, 偽幽門腺 化生の出現がみられる。

としては, 腸上皮化生, 固有腺の萎縮, びらんについて 観察した。

一般に固有腺の萎縮は，腺境界部から幽門腺領域にみ られるものが多いが，なかには腺境界をこえて胃底腺領 域にも認められるるのがある. 胃底腺領域におけ萎縮 の境界のシェーマと組織像を示すが，この高度の萎縮は 肉眼的にもはっきり認められ, 萎縮境界には, リンパ滤 胞の増生や，びらんの修復後の腸上皮化生や偽幽門腺化 生がみられる(図2).

次に no ulcer 例に打ける萎縮性胃炎の分布状況をみ ると, 幽門腺領域あるいは, 腺境界部に限局したものが 69例 $(69 \%)$ と王倒的に多くみられ，高度の萎縮を示す ものは24例と少なかった（図 3).

萎縮の分布状況を各疾患別に比較してみると, 胃角部 潰瘍例では腺境界を越えて胃底腺領域まで萎縮が及ぶも のが多く，これと全体に萎縮のみられるものを合わせて 57\%にみられた（図4）.また高位潰瘍26例についてみる
図 3 ヒト切除胃の萎縮性胃炎の分布 (no ulcer 100例)

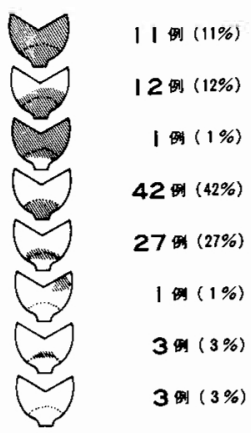

幽門腺領域あるいは腺境界に限局したすのが多く みられる。

図 4 疾患別にみた萎縮性胃炎の分布状況と頻度

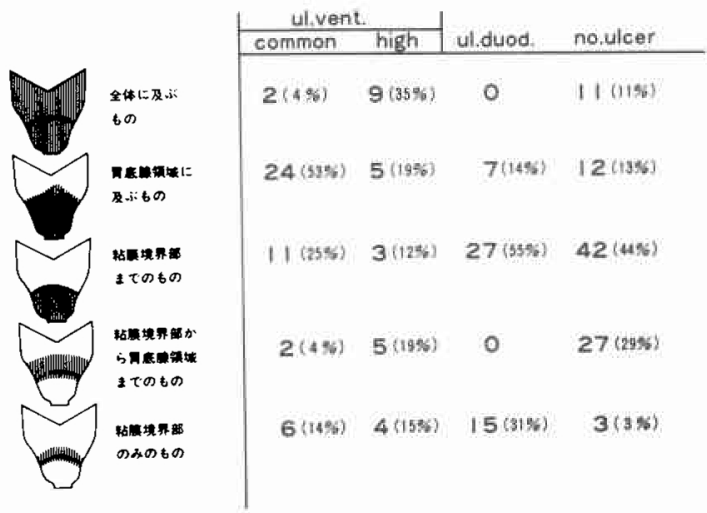

胃潰瘍では萎縮が広範囲に及ぶるのが多い。

と全体に及ぶ萎縮がみられるものが 9 例 (35\%) と多く, 胃角部潰場よりも広い範囲にわたる胃底腺領域の荒廃が 強いことがうかがえた。また高位潰痬では胃底腺領域に おけるびらんの形成が多発してみられ，これは胃角部潰 瘍ではみられない特徵であった。十二指腸潰痬では, no ulcer 例よりもさらに腺境界に限局した軽度例が多くみ られ，高度例はわずか14\%にみられるにすぎなかった。 血管檴築について

墨汁注入法でみた人胃の粘膜血管構築は，胃底腺領域 と幽門腺領域とでは，あさらかに違っていた（図5）.

胃底腺領域では密に配列した森林状を呈する血管群 が，規則的にみられた。これに対し幽門腺領域では血管 分布が粗になり，胃小区毎に，木を植えているような所 見がみられた。そして両者の境界は, 組織学的な境界腺 に一致しており，移行部は血管の配列が不規則になって 
図 5 血管構築からみた境界部（矢印）。矢印は境 界部で，その右側が胃底腺領域，左側は幽門腺領 域である、境界部では，血管の配列が不規則にな っている.

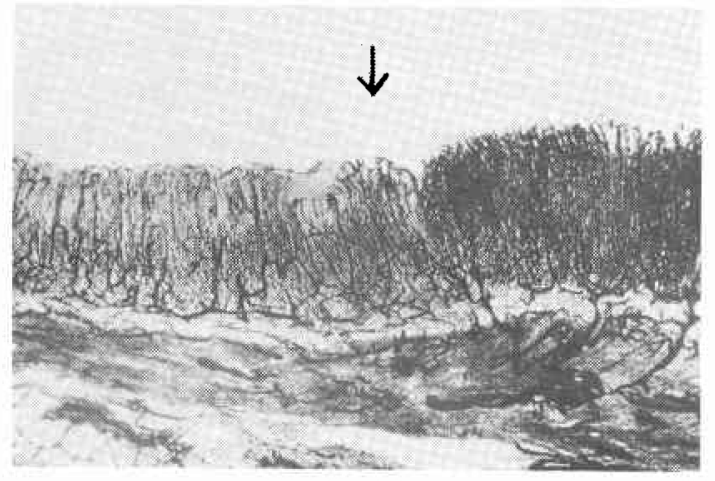

因 6 血管棈筑 の胃炎による变化. 高度胃炎例で は, 血管の蛇行, 扗張がみられ, 配列も不規則に なっている。

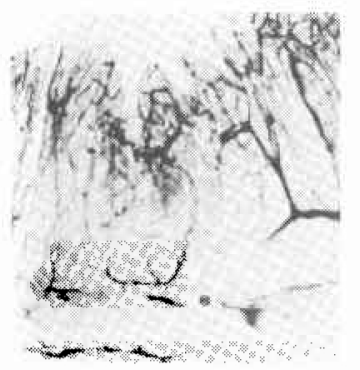

胃焱 軽度

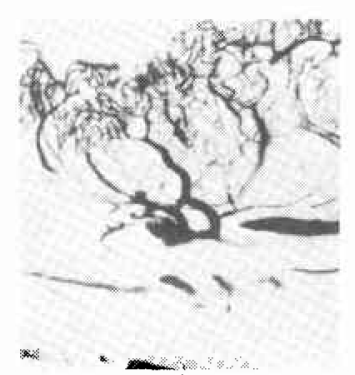

胃炎 高度
いた。この血管構築の胃炎による影響をみてみると，軽 度胃炎例では，樹枝状血管の配列が未だ規則的に保たれ ているが, 高度例ではおしつぶされたように変形してお り，血管の蛇行や桩張がみられ，配列も不規則となって いた（図6）.したがって，腺境界部に括ける血管構築像 から，その部分の血流は特に少ないと考えられこれに慢 性胃炎の変化，とくに固有腺の萎縮が加わると，さらに 血流障害は強くなると考えられた。

\section{血管の器買的変化について}

墨汁注入法による粘膜血管像の所見からも，血管の器 質的変化による細小化などが観察され，とくに萎縮性胃 炎例においては著明であり，胃粘膜血流に血管の器質的 変化の影響が考学られた。 そこで胃潰瘍例に拈ける血管 の器質的変化の状況につき検討した.

潰瘍底における血管变化はいずれの場合にも著明に認 められその程度は潰瘍の経過に相関すると云われる。乙
かし胃潰瘍例において，潰湟から離れた部位にも，著明 な内腔狭小化を伴う血管変化（図7）を認める.そこで 粘膜下層, 固有筋層に和けるこのような血管の器質的変 化をシェーマ化したものであるが（図8）内膜肥厚, 内 腔の狭小化, 弾性板の断裂などが見られるものを高度, 中膜の線維化が主で, 軽度の内膜炎を伴うものを中等度, 血管周囲の線維化のみられるものを軽度として 観察し た. 胃角部潰瘍45例について，血管変化の状況をみてみ ると, (図9), 高度の変化が多く見られるものは15例 (33\%), 中等度の変化が主体であるものは24例 $(54 \%)$, 軽度の変化が見られるものは6例 $(13 \%)$ であった。

次に萎縮性胃炎と血管変化の関係を胃潰瘍例について みると, 血管変化が高度, 中等度例39例は, 萎縮も高度

図 7 著明な血管变化. 内膜の肥厚, 内腔の狭小 化, 内弾性板の断裂, Duplicationを伴っている.

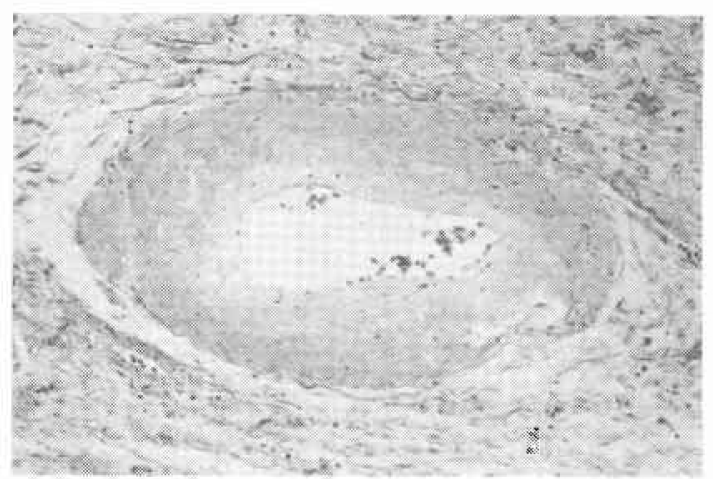

図 8 上段内膜肥厚, 内腔狭小化著明, 中段軽度内 膜炎と中膜の線維化，下段血管周囲の線維化.

血管の器質的变化

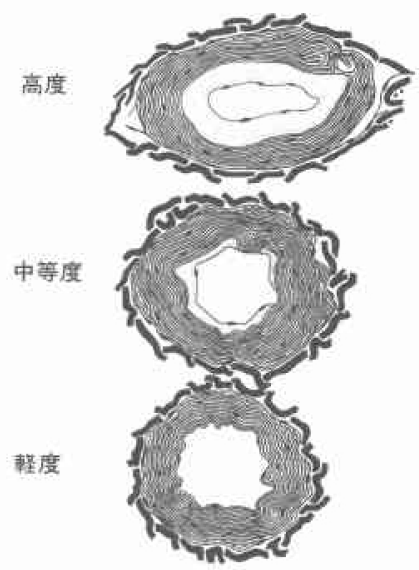


図 9 血管の器質的変化と萎縮との関係. 血管变化 の強いむのほと，萎縮も強く，境界部をこええて ひろがっていく.

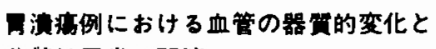
宾縮性用炎の閶連

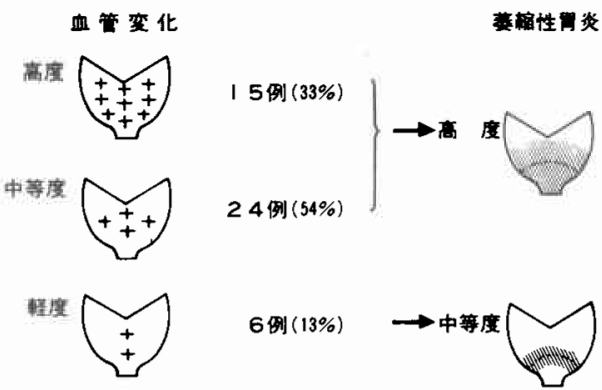

39 例

6例

(1979.2)

であり, 血管のこのような器質的変化も，粘膜の萎縮に 影響を及ぼすであろうと考えられた。十二指腸潰瘍例で は、このような血管変化す少なかった。このよらなこと から，胃潰瘍の発生，ならびに慢性化因子として，血管 の器質的変化や胃粘膜の萎縮性変化が重要であると考え られた。

図10 ホルマリン潰場の組織像と血管変化. 作成 3

日目.びらん形成と動脈の Spasm
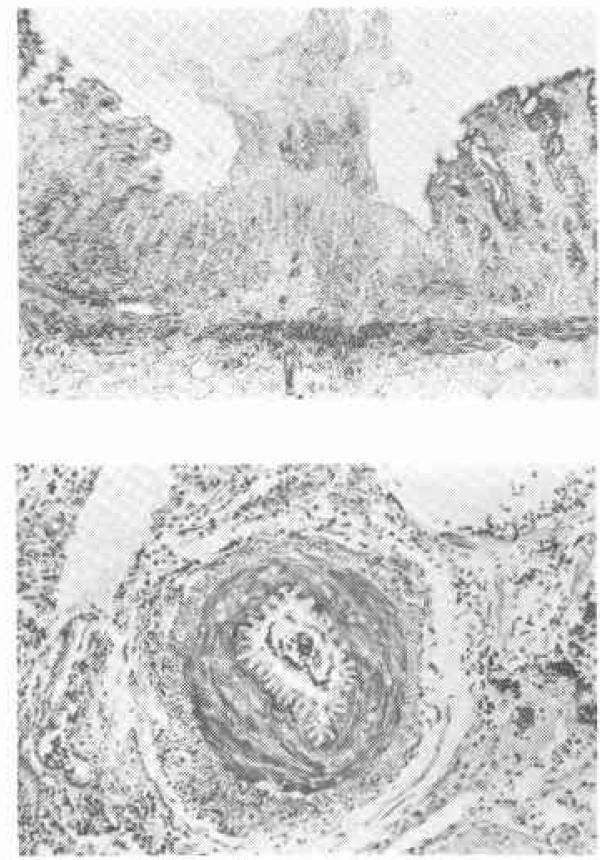

\section{惿性清㿉の発生実験}

そこで，胃壁局所の循環障害ならびに血管変化をつく り，潰瘍の発生を試みるために，ホルマリン動脈内注入 による実験を行った．ホルマリン注入後 3 日目の組織像 をみると，(図10）全層にわたる強い循環障害が認めら れ，粘膜の脱落，びらんが起こっているまたホルマリ ソによる動脈の Spasm や血栓形成が著明に認められ， 内膜に fibrinoid 変性を起こしてくる. 潰場作成後 3 力 月の長期にわたって治癒しなかった例の組織像では（図 11）ヒトの慢性胃潰瘍に近似して扣り, 潰瘍周囲の血管 変化も, 内膜の肥厚や, 弾珄板の断裂など, 人の粘膜下 血管にみられるのと同様の所見を呈していた，また再生 された粘膜は軽度の萎縮を起こしていた.このようなこ とからも, 胃の血管の器質的変化が, 潰瘍の経過に関与 していることが示唆された。

\section{考察}

潰瘍の成因については，Rokitansky（1841）による中 枢神経説をはじめ，Virchow (1853) や Hauser (1883) の循環障害説, Konjetzney（1923）の胃炎説など多数み られれるが，近年攻撃因子と防禦因子のバランス（Hollander. 1954）といらことがとりあげられるようになっ た。

図11 ホルマリン潰瘍の組織像と血管変化. 潰痬作 成後 12 週目. 典形的慢性潰痬と, 内腔狭小化をき たした動脈。
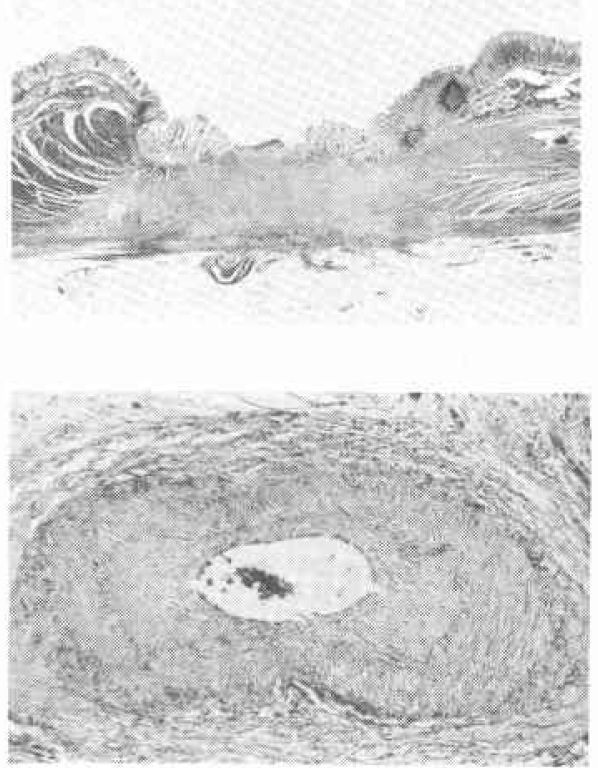
Davenport のいう, $\mathrm{H}^{+}$の Back diffusion による mucosal barrier の破綻ということが脚光をあびた。しか し, 大井の二重規制学説によると, 潰瘍の発生は, 胃局 所の部位的な因子がきわめて重要であるといわれ，局所 的因子をどのように解积するかという点では問題が多 い。また胃潰瘍患者では，十二指腸潰瘍患者に比べて， 低酸例が多いことから考之ても，防禦因子の低下，すな わち粘膜抵抗の減弱化が，より重要な因子であろうと考 えるが，攻撃因子としての，胃液の働きも無視できな い.このように胃潰場の成因としては, 数限りない因子 の複雑な組み合せによっているすのと考兄られるが，わ れわれがとりあげた, 胃粘膜変化としての粘膜の萎縮, 血流におよぼす血管構筑あるいは血管の器質的变化など は，防禦因子のなかのごく一部の問題をとりあげている にすざない，乙かし萎縮性胃炎が好んで腺境界に出現す ることや，腺境界部の血管構築がきわめて貧弱であるこ と, 血管の器質的変化の存在々粘膜萎縮の関係が深いこ とを考えると，これらの因子が，潰瘍の発生ならびに慢 性化に強く影響を及ぼしていると考兄られ，また潰場の 局在性の説明も可能である.この胃粘膜局所のさまざま な変化を考えると, 胃潰瘍の外科的治療の原則は, 二重 規制の法則の面からだけでなく，胃粘膜の抵抗減弱部位
の切除ということが，より必要とおむわれる。したがっ て胃角部潰瘍に対しては, 従来から行われている広範囲 胃切除が，満足のいく術式と考えられる．しかし胃底腺 潰瘍に対しては，胃粘膜の荒廃の強い胃底腺領域も十分 に切除する術式が望ましいと考党る。

$$
\text { まとめ }
$$

胃潰場における萎縮性胃炎や，血管構築，ならびに血 管の器質的変化の特徵を述べるととるに, 外科的治療の 原則について考察した。

\section{参考文献}

1)長尾房大：消化性溃晹の外科療法. 慈医誌, 89: $583-602,1974$

2）長房尾大：消化性潰瘍の手術適応と手術々式の 撰択. 日臨外会誌, 38 (2)：143-147, 1977 .

3) Davenport, H.W., et al.: Functional significance of gastric mucoscal barrier to sodium. G. E., 47: 142-152, 1964.

4) Hollander, F.: Two component mucous barrier its activity in protecting the gastro duodenal mucosa against peptic ulceration. Arch Intern. Med. (Chicago), 93: 107-129, 1954.

5）大井 実：消化性清㿑の 発生と二重規制学説, 昭51, 南江堂, 東京. 